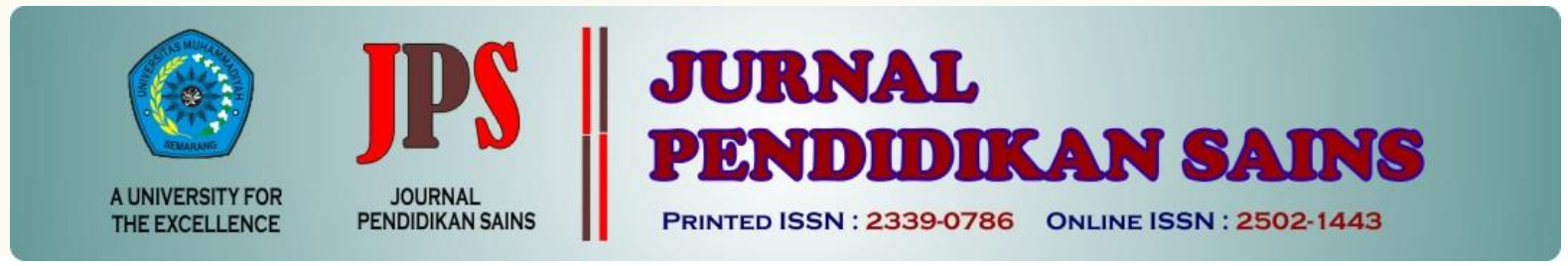

http://jurnal.unimus.ac.id/index.php/JPKIMIA

\title{
PENGARUH PENGGUNAAN MEDIA PEMBELAJARAN STYROBON TERHADAP KREATIVITAS BERPIKIR DAN HASIL BELAJAR KOGNITIF
}

\author{
Silvia Rahmawati ${ }^{1)}$,Agus Kamaludin ${ }^{2)}$ \\ ${ }^{1)}$ Mahasiswi Program Studi Pendidikan KimiaUIN Sunan Kalijaga Yogyakarta \\ ${ }^{2)}$ Dosen Program Studi Pendidikan KimiaUIN Sunan Kalijaga Yogyakarta
}

\begin{tabular}{ll}
\hline \multicolumn{2}{l}{ Article history } \\
\hline Submission & $: 2018-10-03$ \\
Revised & $: 2018-11-29$ \\
Accepted & $: 2019-06-14$
\end{tabular}

Keyword:

Katakunci:

MediaPembelajaran

Styrobon, Kreativitas

Berpikir, Hasil Belajar

Kognitif, Gugus Fungsi

\section{Abstract}

This research aimed to examine the effect of the use of Styrobon learning media on the creative thinking skills and cognitive learning outcomes of $12^{\text {th }}$ grade students on the subject of functional group in chemistry. The type of this research was Quasi Experiment by which the research design was in the form of Non-equivalent Control Group Design. The measurement of students' creative thinking skills used questionnaire data and observation sheets, in which data analysis techniques in questionnaires used non-parametric statistical tests namely Mann-Whitney test and observation sheet data used the observation sheet reference score. While the measurement of cognitive learning outcomes of students used pre-test and posttest questions in which data analysis techniques used nonparametric statistical tests namely Mann-Whitney test. The results of statistical test on the creative thinking skills and cognitive learning outcomes of students were 0.049 and 0.044 (both were $<0.05$ ) which indicates the significance of the media use effect. These showed that the use of Styrobon learning media influenced creative thinking skill and cognitive learning outcomes of the students.

\section{Pendahuluan}

Keberadaan agama Islam telah menjadi sumber motivasi pengembangan ilmu. Agama Islam yang bersumberkan $\mathrm{Al}$ Qur'an dan Hadis, mengajar dan mendidik manusia untuk berpikir dan menganalisis tentang unsur kejadian alam semesta beserta isinya. Dengan demikian, agama telah memberikan ruang lingkup bagi pengembangan ilmu dan teknologi serta pemikiran bahwa kemajuan teknologi jangan sampai menjauhkan apalagi menghapuskan peran agama (Arifin, M. 1995: 131). Kemampuan dalam berpikir dan menganalisis tersebut tidak hanya diperlukan untuk menghasilkan dan mengembangkan suatu ilmu pengetahuan, tetapi juga sebagai kemampuan yang dapat menemukan atau menyelesaikan berbagai persoalan yang dihadapi umat. Salah

*Corresponding Author:

$\begin{array}{ll}\text { Nama } & \text { : Silvia Rahmawati } \\ \text { Lembaga } & \text { : UIN Sunan Kalijaga Yogyakarta } \\ \text { Email } & \text { : vivi.silvia34@gmail.com }\end{array}$


satu kemampuan berpikir yang perlu dikembangkan yaitu kreativitas.

Pentingnya mengembangkan kreativitas peserta didik sebenarnya sudah ditekankan oleh pemerintah dalam Kurikulum 2013, yang ingin mengembangkan keseimbangan antara pengembangan sikap spiritual dan sosial, rasa ingin tahu, kreativitas, kerja sama dengan kemampuan intelektual dan psikomotorik (Nuh, M. 2013: 3). Sejalan dengan hal tersebut, kreativitas juga menjadi salah satu kecakapan yang dibutuhkan oleh setiap individu di era globalisasi ini, selain kecakapan berupa keterampilan berpikir kritis, kerjasama, dan komunikasi (Nizam, 2016: 2).

Sayangnya, pendidikan di Indonesia masih kurang memberi peluang bagi pengembangan kreativitas. Ranah di sekolah yang paling utama dilatih adalah ranah kognitif yang meliputi pengetahuan, ingatan, dan kemampuan berpikir logis atau penalaran. Sementara perkembangan ranah afektif (sikap dan perasaan) dan ranah psikomotorik (keterampilan) serta ranah lainnya kurang diperhatikan (Juliantine, T. 2009: 2). Selain itu, pandangan klasik terhadap kreativitas menjadikan pengembangan kreativitas cenderung diabaikan, sebab kreativitas dianggap sebagai bakat bawaan yang melekat pada individu tertentu dan tidak dapat dipengaruhi oleh faktor luar (Mahmudi, A. 2007: 43). Tentu saja hal tersebut menyebabkan penelitian mengenai kreativitas masih jarang dilakukan, sebagaimana yang dikemukakan oleh Guilford dalam Utami Munandar (2002: 7) yang menyatakan bahwa penelitian dan pengembangan kreativitas dalam dunia pendidikan formal masih sangat kurang mendapat perhatian.

Kreativitas peserta didik yang kurang diperhatikan dan diapresiasi dalam proses pembelajaran ini menyebabkan peserta didik tidak mau bahkan takut untuk melakukan suatu hal yang baru. Padahal kreatif bukan hanya kemampuan untuk menghasilkan produk baru saja melainkan kemampuan menciptakan sebuah solusi yang tidak terpaku pada satu jawaban benar pun dapat dikatakan kreatif (Humaeroh, I. 2016: 3). Oleh karena itu, kreativitas berpikir sangat diperlukan oleh peserta didik dalam setiap proses pembelajaran, termasuk saat pembelajaran kimia.

Kreativitas yang diperlukan dalam pembelajaran kimia antara lain dalam hal menyelesaikan soal-soal yang menantang, soalsoal yang berhubungan dengan penerapan kimia dalam kehidupan sehari-hari, dan percobaan atau eksperimen serta metode ilmiah yang berhubungan dengan ilmu kimia (Ahmar, D. S. 2016: 158). Hal tersebut sesuai dengan salah satu tujuan dalam mempelajari kimia yaitu untuk memperoleh pengalaman dalam menerapkan metode ilmiah melalui percobaan atau eksperimen, dimana peserta didik melakukan pengujian hipotesis dengan merancang percobaan melalui pemasangan instrumen, pengambilan, pengolahan, dan penafsiran data, serta menyampaikan hasil percobaan secara lisan dan tertulis. Pernyataan tersebut menunjukkan bahwa dalam mempelajari ilmu kimia dibutuhkan kreativitas peserta didik dalam berpikir. Oleh karena itu pengembangan kreativitas berpikir peserta didik merupakan salah satu tanggung jawab pendidik yang sangat diperlukan.

Upaya dalam mengembangkan kreativitas berpikir peserta didik dapat dilakukan dengan berbagai macam inovasi, salah satunya yaitu melalui media pembelajaran. Media pembelajaran memiliki peran yang penting dalam pengembangan kreativitas peserta didik karena dapat meningkatkan proses dan hasil pengajaran yang berkenan dengan taraf kreativitas berpikir peserta didik (Maghfirah, dkk, 2017: 35). Selain itu, proses pembelajaran pada hakikatnya adalah proses komunikasi antara pendidik yang berperan sebagai pengantar pesan dan peserta didik sebagai penerima pesan, dimana proses komunikasi tersebut ada kalanya mengalami hambatan, sehingga pesan yang diterima tidak sesuai dengan maksud yang disampaikan. Oleh sebab itu, dalam suatu proses komunikasi diperlukan saluran untuk mempermudah penyampaian pesan, yaitu media pembelajaran (Sanjaya, W. 2011: 205-206).

Penggunaan media tentunya sangat diperlukan dalam pembelajaran kimia, karena karakteristik mata pelajaran kimia bersifat abstrak. Di samping itu, kebanyakan peserta didik menganggap mata pelajaran kimia sebagai mata pelajaran yang sulit dan hanya sedikit peserta didik yang melanjutkan pendidikan di bidang kimia (Sirhan, 2007). Salah satu penyebabnya adalah penyajian materi kimia yang kurang menarik dan membosankan, sehingga mengakibatkan banyak peserta didik kurang menguasai konsep-konsep dasar pelajaran kimia (Rahayu, I. 2009: 12). 
Berdasarkan hasil wawancara ${ }^{1}$ dengan tiga orang pendidik kimia di Yogyakarta, menyatakan bahwa salah satu materi kimia yang dianggap sulit oleh peserta didik kelas XII pada semester genap adalah materi Gugus Fungsi. Kendala yang sering dihadapi yaitu peserta didik kesulitan dalam mengingat struktur dari gugus fungsi yang bervariasi sehingga kesulitan dalam memberikan tata nama dan membuat isomernya. Hal tersebut sesuai dengan hasil penelitian Munzil, dkk (2017: 1) yang menyatakan bahwa gugus fungsi merupakan salah satu materi kimia organik yang masih dianggap sulit, dimana kesulitan pada materi ini dikarenakan beberapa faktor, yakni multidimensi materi kimia organik, sikap peserta didik, dan adanya miskonsepsi.

Selain itu, dari hasil wawancara tersebut diketahui pula bahwa penilaian pada peserta didik selama ini hanya sebatas penilaian kognitif dan afektif yang berkaitan dengan keaktifan peserta didik pada saat pembelajaran di kelas saja, sedangkan aspek lain seperti kreativitas berpikir masih jarang dilakukan oleh pendidik. Kemudian saat proses pembelajaranpun pendidik hanya menggunakan media papan tulis atau power point saja dan belum menggunakan media lain yang menyebabkan pengetahuan peserta didik sebatas apa yang telah disampaikan oleh pendidik sehingga peserta didik kurang dapat mengembangkan apa yang telah diperoleh dalam pembelajaran. Hal ini menunjukkan bahwa kreativitas peserta didik masih rendah dan memerlukan peningkatan.

Salah satu media yang dapat digunakan dalam pembelajaran kimia materi pokok gugus fungsi adalah media styrobon. Media styrobon berupa media yang terbuat dari styrofoam yang berbentuk unsur $\mathrm{C}, \mathrm{H}$, dan $\mathrm{O}$, dan dilengkapi dengan balok penghubung. Kelebihan media ini yaitu dapat menunjukkan materi gugus fungsi yang masih bersifat abstrak menjadi lebih konkret, sehingga informasi yang diterima oleh peserta didik akan lebih optimal. Selain itu, peserta didik juga mendapatkan pengalaman belajar yang menyenangkan karena dapat belajar sambil bermain. Dengan demikian, media styrobon diharapkan dapat merangsang kreativitas berpikir peserta didik dan dapat

\footnotetext{
${ }^{1}$ Hasil Wawancara dengan Ibu Nuning Setianingsih, S.Si, M.Pd dan Ibu Siwi Hidayati, S.Pd Pendidik Mata Pelajaran Kimia di MAN 2 Sleman pada tanggal 3 dan 15 November 2017 serta Ibu Dra. Ninik Indriyanti Pendidik Mata Pelajaran Kimia di MAN 4 Bantul pada tanggal 12 Januari 2018
}

mempermudah peserta didik dalam memahami materi gugus fungsi.

\section{Metode Penelitian}

\section{Jenis Penelitian}

Penelitian ini merupakan penelitian eksperimen semu (Quasi experiment). Eksperimen semu ini memerlukan adanya treatment yang biasanya ditujukan kepada kelompok eksperimen dan diharapkan treatment ini dapat memberikan hasil yang berbeda, artinya jauh lebih baik dari pada kelompok kontrol (Darmawan, 2013: 51-52).

Desain penelitian yang digunakan dalam penelitian ini adalah nonequivalent control group design atau pretest-posttest control group design, yaitu kelompok eksperimen dan kontrol sebelum diberikan perlakuan diberikan pretest untuk mengetahui keadaan awal antara kelompok eksperimen dan kelompok kontrol, dan setelah diberikan perlakuan dilakukan posttest untuk mengetahui keadaan akhir antara kelompok eksperimen dan kelompok kontrol (Sugiyono, 2015:116).

\section{Waktu dan Tempat Penelitian}

Penelitian ini dilaksanakan di MAN 4 Bantul yang beralamat di Jalan Majopahit, Pranti, Banguntapan, Bantul, pada kelas XII MIA semester genap tahun ajaran 2017/2018. Waktu penelitian dilaksanakan dari bulan Januari sampai Februari 2018.

\section{Populasi dan Sampel Penelitian}

Populasi pada penelitian ini yaitu seluruh peserta didik kelas XII MIA di MAN 4 Bantul tahun ajaran 2017/2018. Sementara teknik pengambilan sampelnya yaitu berupa sampling jenuh. Menurut Sugiyono (2015: 61) sampling jenuh adalah teknik penentuan sampel bila semua anggota populasi digunakan sebagai sampel. Hal tersebut dikarenakan kelas XII MIA di MAN 4 Bantul hanya terdapat dua kelas, sehingga kedua kelas tersebut langsung dapat dibagi menjadi kelompok eksperimen dan kelompok kontrol. Adapun dalam menentukan kelas mana yang akan menjadi kelompok eksperimen atau kelompok kontrol, peneliti menggunakan prinsip cluster random sampling, dimana penentuan sampel dengan teknik ini mengasumsikan masing-masing kelas dari keseluruhan populasi dianggap memiliki kemampuan yang sama dan atau hampir sama yang dilihat dari uji homogenitas pada nilai ujian akhir semester ganjil serta hasil 
persetujuan dengan pendidik mata pelajaran kimia.

\section{Intrumen dan Teknik Pengumpulan Data}

Instrumen penelitian yang digunakan meliputi instrumen pembelajaran yang terdiri dari Rencana Pelaksanaan Pembelajaran (RPP) dan Lembar Kerja Peserta Didik (LKPD), serta instrumen pengumpulan data yang berupa angket kreativitas berpikir (terdapat 20 pernyataan dengan 10 pernyataan positif dan 10 pernyataan negatif), lembar observasi (dibuat dalam bentuk rating scale 1-3), dan soal tes hasil belajar (pretest dan posttest) berbentuk uraian. Instrumen tersebut terlebih dahulu dilakukan uji validitas instrumen meliputi validitas isi dan validitas konstruk ke dosen ahli serta validitas empiris kepada peserta didik, kemudian ditentukan reliabilitasnya. Sementara itu teknik pengumpulan data yang digunakan dalam penelitian ini yaitu dengan menggunakan wawancara, studi dokumenter, angket kreativitas berpikir, lembar observasi, serta tes hasil belajar.

\section{Teknik Analisis Data}

1. Angket Kreativitas Berpikir

Data angket berupa data kuantitatif dan dianalisis berdasarkan penskoran jawaban angket yang telah dibuat, kemudian dihitung jumlah skor sesuai dengan aspek yang diamati. Data angket kreativitas berpikir merupakan data ordinal, sehingga dilakukan uji statistik nonparametrik yaitu dengan uji Mann-Whitney menggunakan bantuan program SPSS 16.0. Selain diuji statistika, data angket kreativitas berpikir juga dihitung persentase pada masing-masing kelompok sampel dengan rumus sebagai berikut.

Persentase $=\frac{\text { skor per butir }}{\text { skor maksimal }} \times 100 \%$

Menurut Arikunto (2009: 245) jumlah skor yang diperoleh dipersentasekan dan dikategorikan sesuai dengan kualifikasi hasil angket kreativitas berpikir yang dapat dilihat dalam Tabel 1 berikut.

Tabel 1. Kualifikasi Persentase Skor Angket

\begin{tabular}{cc}
\hline $\begin{array}{c}\text { Persentase skor yang } \\
\text { diperoleh }\end{array}$ & Kategori \\
\hline $80 \% \leq \mu \leq 100 \%$ & Tinggi \\
\hline $60 \% \leq \mu \leq 79 \%$ & Sedang \\
\hline $40 \% \leq \mu \leq 59 \%$ & Kurang \\
\hline $20 \% \leq \mu \leq 39 \%$ & Rendah \\
\hline $0 \% \leq \mu \leq 19 \%$ & Sangat Rendah \\
\hline
\end{tabular}

2. Lembar Observasi
Data hasil observasi kreativitas berpikir peserta didik kelompok eksperimen dan kelompok kontrol selama kegiatan pembelajaran dideskripsikan berdasarkan kriteria tertentu. Penentuan kriteria menggunakan skala Likert yang dimodifikasi menjadi skala 3. Kategori penskoran sikap peserta didik dari data hasil observasi dapat dilihat dalam Tabel 2 berikut (Kemendikbud, 2013: 131).

Tabel 2. Kategori Penskoran Data Hasil Observasi

\begin{tabular}{|c|c|c|}
\hline Nilai Skala & Predikat & Kategori \\
\hline $86-100$ & A & \multirow{2}{*}{ Sangat Baik } \\
\hline $81-85$ & A- & \\
\hline $76-80$ & $\mathrm{~B}+$ & \multirow{3}{*}{ Baik } \\
\hline $71-75$ & $\mathrm{~B}$ & \\
\hline $66-70$ & B- & \\
\hline $61-65$ & $\mathrm{C}+$ & \multirow{3}{*}{ Cukup } \\
\hline $56-60$ & $\mathrm{C}$ & \\
\hline $51-55$ & C- & \\
\hline $46-50$ & D+ & \multirow{2}{*}{ Kurang } \\
\hline $0-45$ & $\mathrm{D}$ & \\
\hline
\end{tabular}

3. Hasil Belajar Kognitif

Analisis tes hasil belajar kognitif dapat dilakukan dengan uji statistik. Namun sebelum hasil tes dianalisis dengan uji statistik, terlebih dahulu dilakukan uji prasyarat berupa uji normalitas dan uji homogenitas. Jika data berdistribusi normal maka dapat dilakukan uji statistik parametrik berupa uji Independent Sample T-Test, namun jika data yang dihasilkan tidak berdistribusi normal maka menggunakan uji statistik nonparametrik yaitu uji MannWhitney. Pada penelitian ini, peneliti menggunakan uji Mann-Whitney dikarenakan data yang diperoleh tidak berdistribusi normal.

\section{Hasil Penelitian dan Pembahasan}

\section{Hasil Penelitian}

1. Analisis Data Angket Kreativitas Berpikir Analisis data angket kreativitas berpikir dilihat berdasarkan data angket kreativitas berpikir pada kelompok eksperimen dan kelompok kontrol yang diberikan setelah pembelajaran selesai. Angket kreativitas berpikir ini berisi 20 pernyataan yang telah dilakukan uji validasi, meliputi validasi isi dan konstruk.

Data hasil angket kreativitas berpikir tersebut langsung dilakukan uji statistika berupa uji Mann-Whitney, karena untuk mengkaji pengaruh dari penggunaan media pembelajaran styrobon terhadap kreativitas berpikir peserta didik. Adapun hasil 
perhitungan dengan menggunakan uji MannWhitney diperoleh hasil Asymp. Sig. (2tailed) sebesar 0,049. Hal ini menunjukkan bahwa nilai tersebut $<0,05$ maka $\mathrm{H}_{0}$ ditolak, yang berarti bahwa terdapat perbedaan yang signifikan antara kelompok eksperimen dan kelompok kontrol, sehingga terdapat pengaruh penggunaan media pembelajaran styrobon terhadap kreativitas berpikir peserta didik.

2. Analisis Data Lembar Observasi

Analisis data lembar observasi dilakukan dengan cara menghitung skor dari seluruh aspek yang diamati setiap pertemuan pada materi gugus fungsi. Lembar observasi dalam penelitian ini hanya dijadikan sebagai data pendukung untuk membuktikan bahwa peserta didik pada kelompok kontrol dan kelompok eksperimen memiliki kreativitas berpikir yang berbeda sebagai akibat dari pengaruh penggunaan media pembelajaran styrobon, sehingga tidak dilakukan uji statistika nonparametrik.

Berdasarkan data analisis lembar observasi kreativitas berpikir peserta didik saat proses pembelajaran, rata-rata skor lembar observasi dari pertemuan pertama sampai pertemuan keempat pada kelompok kontrol sebesar 67,28 sedangkan pada kelompok eksperimen sebesar 74,71. Hal ini menunjukkan bahwa kreativitas berpikir peserta didik pada kelompok eksperimen tergolong dalam kategori baik dengan predikat B dan pada kelompok kontrol tergolong dalam kategori baik namun dengan predikat B-.

Selain itu, berdasarkan hasil perhitungan lembar observasi kreativitas berpikir yang dihitung tiap pertemuan menunjukkan bahwa kreativitas berpikir peserta didik baik pada kelompok kontrol maupun kelompok eksperimen mengalami peningkatan. Hal ini disebabkan karena pencapaian skor dalam kategori-kategori kreativitas berpikir peserta didik semakin tinggi.

3. Analisis Data Hasil Belajar Kognitif

\section{a. Data Pretest}

Data pretest merupakan data yang diambil oleh peneliti ketika sampel (kelompok eksperimen dan kelompok kontrol) belum diberikan perlakuan, yang bertujuan untuk mengetahui kemampuan awal peserta didik sebelum pembelajaran gugus fungsi dimulai. Data pretest ini berupa data hasil tes hasil belajar awal peserta didik yang tersaji pada Tabel 3 berikut.

Tabel 3. Hasil Pretest Kelompok Kontrol dan Eksperimen

\begin{tabular}{|c|c|c|c|}
\hline \multirow{2}{*}{ Kelas } & \multicolumn{2}{|c|}{ Nilai } & \multirow{2}{*}{$\begin{array}{l}\text { Rata- } \\
\text { Rata }\end{array}$} \\
\hline & Tertinggi & Terendah & \\
\hline Kontrol & 18,75 & 2,08 & 5,81 \\
\hline $\begin{array}{l}\text { Eksperi } \\
\text { men }\end{array}$ & 12,50 & 2,02 & 8,02 \\
\hline
\end{tabular}

Hasil nilai pretest kemudian dilakukan uji prasyarat berupa uji normalitas dan homogenitas. Pada uji normalitas digunakan uji normalitas Kolmogorov-smirnov dengan nilai signifikansi $\quad \alpha \quad(0,05), \quad$ yang menunjukkan bahwa baik pada kelompok kontrol maupun eksperimen keduanya memiliki nilai Sig $<0,05$, yaitu berturut-turut sebesar 0,003 dan 0,040. Artinya, hasil pretest pada kelompok kontrol maupun eksperimen sama-sama tidak berdistribusi normal. Hal ini dikarenakan sebaran nilai di bawah dan di atas nilai frekuensi tertinggi tidak seimbang.

Selanjutnya dilakukan uji homogenitas untuk menguji bahwa kelompok-kelompok yang dibandingkan memiliki variansi yang sama agar uji prasyarat terpenuhi dan bisa dilakukan uji selanjutnya. Homogenitas variansi ditentukan dengan melihat nilai signifikansi pada Test of Homogeneity of Variances. Hasil uji homogenitas nilai pretest peserta didik diperoleh nilai signifikansi $>\alpha(0,05)$, yaitu sebesar 0,319 . Dengan demikian data nilai pretest peserta didik mempunyai variansi yang sama atau homogen.

Data yang dihasilkan dari uji prasyarat menunjukkan bahwa data tersebut tidak terdistribusi normal walaupun variansinya homogen, sehingga dilakukan uji hipotesis menggunakan uji statistik nonparametrik yaitu uji Mann-Whitney. Uji Mann-Whitney data pretest ini merupakan uji kesetaraan rata-rata untuk mengetahui kesamaan kemampuan awal peserta didik pada kelompok eksperimen dan kelompok kontrol. Adapun hasil uji MannWhitney nilai pretest kreativitas berpikir peserta didik diperoleh nilai Asymp. Sig. (2-tailed) $>\alpha(0,05)$, yaitu 
sebesar 0,141. Hal ini menunjukkan bahwa tidak terdapat perbedaan yang signifikan antara nilai pretest kelompok eksperimen dengan nilai pretest kelompok kontrol, sehingga kemampuan awal peserta didik yang berada di kelompok eksperimen dan kelompok kontrol adalah sama.

b. Data Posttest

Data posttest merupakan data yang diambil oleh peneliti untuk mengetahui kemampuan akhir peserta didik mengenai materi gugus fungsi setelah peserta didik memperoleh perlakuan. Adapun hasil posttest kelompok kontrol dan eksperimen dapat dilihat dalam Tabel 4 berikut

Tabel 4. Hasil Posttest Kelompok Kontrol dan Eksperimen

\begin{tabular}{lccc}
\hline \multirow{2}{*}{ Kelas } & \multicolumn{2}{c}{ Nilai } & Rata- \\
& Tertinggi & Terendah & Rata \\
\hline Kontrol & 100 & 18,75 & 73,23 \\
\hline $\begin{array}{l}\text { Eksperi } \\
\text { men }\end{array}$ & 100 & 54,17 & 81,78 \\
\hline
\end{tabular}

Hasil nilai posttest kemudian dilakukan uji prasyarat berupa uji normalitas dan homogenitas. Berdasarkan hasil uji normalitas nilai posttest menunjukkan bahwa pada kelompok kontrol memiliki nilai Sig. > 0,05 yaitu 0,179 dan pada kelompok eksperimen memiliki nilai Sig. $<0,05$ yaitu 0,001 . Artinya, hasil posttest pada kelompok kontrol berdistribusi normal, sedangkan pada kelompok eksperimen tidak berdistribusi normal. Kemudian berdasarkan hasil uji homogenitas diperoleh nilai signifikansi $>\alpha(0,05)$, yaitu sebesar 0,064. Dengan demikian dapat disimpulkan bahwa data nilai posttest peserta didik mempunyai variansi yang sama atauhomogen.

Sama halnya dengan nilai pretest, uji hipotesis pada nilai posttest dilakukan dengan menggunakan uji Mann-Whitney, karena data yang dihasilkan dari uji normalitas menunjukkan bahwa masih terdapat data yang tidak berdistribusi normal. Uji Mann-Whitney data posttest ini menunjukkan bahwa nilai Asymp. Sig. (2-tailed $)<\alpha(0,05)$ yaitu sebesar 0,044 sehingga hipotesis nol $\left(\mathrm{H}_{0}\right)$ ditolak, artinya terdapat perbedaan yang signifikan dari hasil belajar peserta didik kelompok eksperimen dan kelompok kontrol. Dengan demikian, dapat disimpulkan bahwa terdapat pengaruh penggunaan media pembelajaran styrobon terhadap hasil belajar kognitif peserta didik.

\section{Pembahasan}

1. Deskripsi Proses Pembelajaran

Proses pembelajaran pada kelompok kontrol dan kelompok eksperimen diberikan perlakuan yang berbeda dalam jenis media yang digunakan. Pembelajaran pada kelompok kontrol menggunakan media pembelajaran yang biasa digunakan di sekolah, seperti papan tulis dan power point, sedangkan pembelajaran pada kelompok eksperimen menggunakan media pembelajaran berupa styrobon. Proses pembelajaran pada kelompok kontrol dan kelompok eksperimen dilakukan sebanyak 5 kali pertemuan dengan setiap pertemuan $2 \mathrm{x}$ 45 menit.

Media pembelajaran styrobon yang digunakan di kelompok eksperimen merupakan media pembelajaran berbentuk tiga dimensi yang berupa styrofoam berbentuk huruf $\mathrm{C}, \mathrm{H}$, dan $\mathrm{O}$ yang dilengkapi dengan batang penghubung. Cara penggunaannya yaitu dengan menyusunnya di atas papan yang sudah disediakan maupun langsung di atas meja belajar peserta didik. Sebelum digunakan oleh peserta didik terlebih dahulu peneliti menerangkan bagaimana cara menggunakannya.

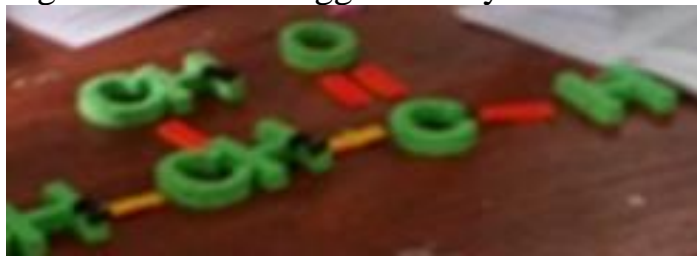

Gambar 1. Media Styrobon

Pembelajaran dengan menggunakan media pembelajaran styrobon pada kelompok eksperimen ini dilakukan dengan membagi peserta didik ke dalam empat buah kelompok, dengan setiap pertemuan susunan anggota tiap kelompoknya berbeda-beda. Selain membagi kelompok, peneliti juga membagi materi diskusi. Ada dua macam diskusi, yang pertama diskusi mengenai materi yang akan dipelajari dan yang kedua diskusi tentang proses pengerjaan latihan soal. Selama proses diskusi, peserta didik menggunakan media styrobon sebagai alat bantu mereka dalam memahami materi tersebut. Meskipun mengalami sedikit kesulitan, peserta didik terlihat semangat 
saat menggunakan media styrobon dalam berdiskusi bersama kelompoknya masingmasing. Setelah diskusi selesai, beberapa kelompok diminta untuk mempresentasikan hasil diskusinya di depan kelas dengan menggunakan media pembelajaran styrobon.

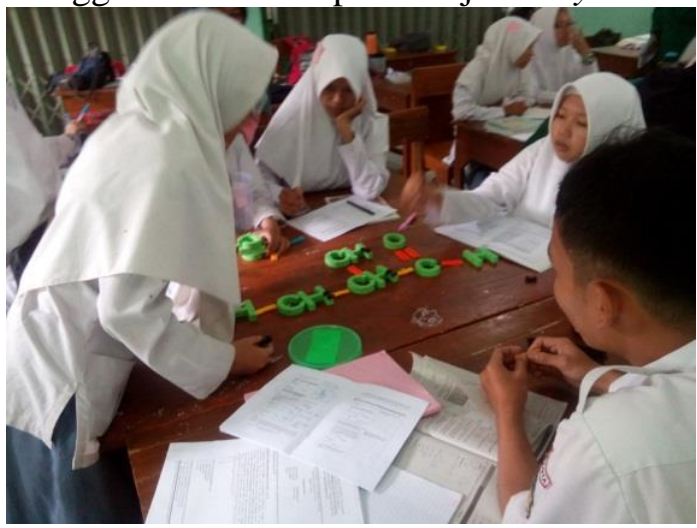

Gambar 2. Peserta Didik menggunakan Media Pembelajaran Styrobon

Sementara itu, proses pembelajaran di kelompok kontrol menggunakan media yang biasa digunakan di sekolah, diantaranya yaitu papan tulis dan power point. Sama halnya dengan kelompok eksperimen, peneliti membagi peserta didik ke dalam empat kelompok, dengan setiap pertemuan susunan anggota tiap kelompoknya berbedabeda. Selain membagi kelompok, peneliti juga membagi materi diskusi yang sama seperti pada kelompok eksperimen, yaitu diskusi mengenai materi yang akan dipelajari dan diskusi dalam proses pengerjaan latihan soal. Setelah diskusi selesai, beberapa kelompok diminta untuk mempresentasikan hasil diskusinya di depan kelas, baik dengan menggunakan power point yang telah disediakan maupun dengan mencatatnya di papan tulis.

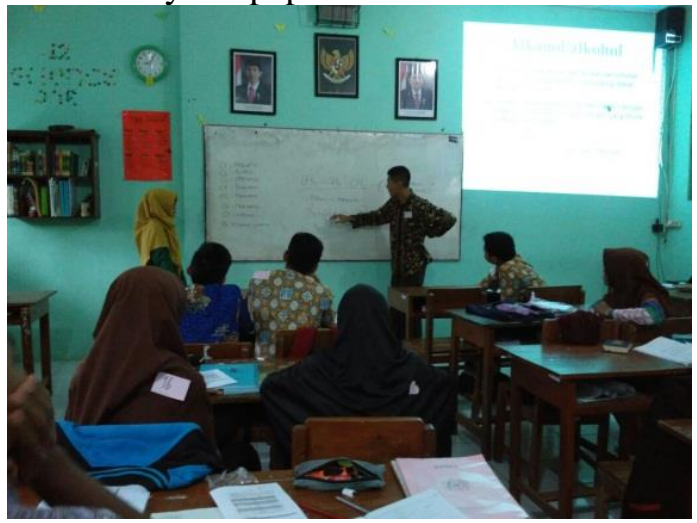

Gambar 3. Peserta Didik Menggunakan Media Papan Tulis

2. Kajian Pengaruh Media Pembelajaran Styrobon terhadap Kreativitas Berpikir Peserta Didik
Kreativitas berpikir peserta didik dalam penelitian ini diketahui melalui angket. Angket ini termasuk ke dalam penilaian nontes, yang akan mengkaji pengaruh media pembelajaran styrobon terhadap kreativitas berpikir peserta didik. Angket diberikan kepada peserta didik kelompok kontrol dan kelompok eksperimen setelah proses pembelajaran materi gugus fungsi selesai disampaikan. Adapun hasil analisis skor angket kreativitas berpikir kelompok eksperimen dan kelompok kontrol untuk skor tiap aspeknya dapat dilihat dalam Gambar 4.

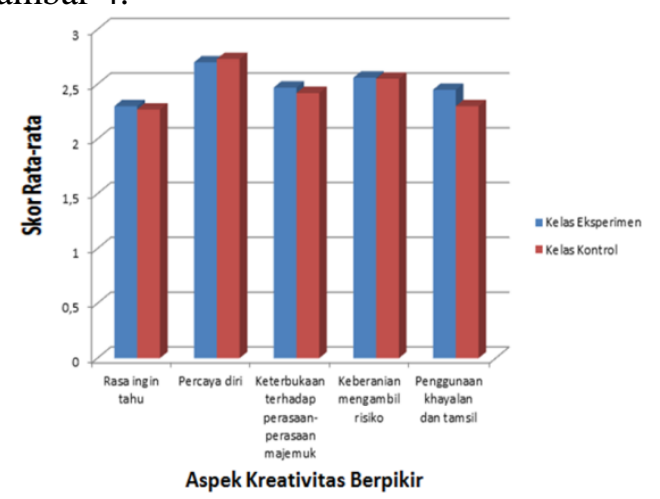

Gambar 4. Grafik Skor Rata-Rata Angket Kreativitas Berpikir Tiap Aspek

Berdasarkan grafik di atas, angket kreativitas berpikir kelompok eksperimen lebih tinggi daripada kelompok kontrol. Pada angket kreativitas berpikir aspek percaya diri, kelompok kontrol memperoleh skor rata-rata lebih tinggi daripada kelompok eksperimen. Hal ini disebabkan karena peserta didik pada kelompok kontrol sudah terbiasa menggunakan media pembelajaran power point daripada peserta didik kelompok eksperimen yang baru menggunakan media styrobon. Apsek keberanian mengambil resiko juga tidak berbeda jauh antara kelompok kontrol dan kelompok eksperimen. Hal ini disebabkan karena peserta didik baik di kelompok kontrol ataupun kelompok eksperimen tidak takut salah dalam menjelaskan secara detail langkah-langkah penyelesaian soal.

Sementara itu, hasil dari perhitungan angket kreativitas berpikir pada kelompok kontrol dan kelompok eksperimen dapat dilihat dalam Tabel 5 berikut.

Tabel 5. Hasil Perhitungan Angket dan Kategori Kreativitas Berpikir

\begin{tabular}{|c|c|c|}
\hline Kelompok & $\begin{array}{c}\text { Skor Rata- } \\
\text { rata }\end{array}$ & Kategori \\
\hline Kontrol & $79,24 \%$ & Sedang \\
\hline Eksperimen & $82,53 \%$ & Tinggi \\
\hline
\end{tabular}


diperoleh dari angket kreativitas berpikir pada kelompok kontrol dan kelompok eksperimen dapat dilihat bahwa rata-rata persentase skor angket pada kelompok eksperimen lebih besar daripada rata-rata persentase skor angket pada kelompok kontrol, dimana pada kelompok eksperimen memperoleh skor $82,53 \%$ sedangkan kelompok kontrol memperoleh skor 79,24\%. Dengan demikian, kreativitas berpikir pada kelompok eksperimen termasuk dalam kategori tinggi sedangkan kreativitas berpikir kelompok kontrol termasuk dalam kategori sedang. Selain dari hasil deskriptif tersebut, data angket dianalisis untuk mengkaji pengaruh penggunaan media pembelajaran styrobon terhadap kreativitas berpikir peserta didik dengan uji statistika berupa uji Mann-Whitney. Hasil uji statistika menggunakan uji Mann-Whitney menghasilkan nilai Sig. sebesar 0,049 yang lebih kecil dari 0,05. Artinya, penggunaan media pembelajaran styrobon berpengaruh terhadap kreativitas berpikir peserta didik.

Hasil dari data angket kreativitas berpikir untuk mengukur kreativitas berpikir peserta didik juga didukung oleh data lembar observasi. Lembar observasi ini diisi oleh empat orang observer (mahasiswa pendidikan kimia yang mengambil penelitian eksperimen) yang bertugas sebagai pengamat selama proses pembelajaran berlangsung, baik di kelompok kontrol maupun di kelompok eksperimen. Sebelum melakukan pengamatan, peneliti terlebih dahulu melakukan breafing kepada keempat observer untuk menyamakan persepsi mengenai pengisian lembar observasi yang telah dibuat. Setelah itu, observer dapat melakukan pengamatan terhadap masing-masing peserta didik pada setiap aspek yang diamati dalam setiap proses pembelajaran yang dilakukan peneliti di kelompok kontrol maupun di kelompok eksperimen.

Pengisian lembar observasi dilakukan pada setiap pertemuan ketika peserta didik melakukan diskusi, presentasi, maupun tanya-jawab. Setelah proses pembelajaran selesai, data hasil pengamatan yang telah diisi oleh observer kemudian dianalisis untuk mengetahui skor lembar observasi pada setiap pertemuan.

Berdasarkan data skor lembar observasi dari setiap pertemuan, maka dapat dihitung rata-rata skor lembar observasi dari pertemuan pertama sampai pertemuan terakhir pada kelompok kontrol dan kelompok eksperimen. Dari data hasil perhitungan lembar observasi dapat diketahui bahwa rata-rata skor lembar observasi kelompok kontrol sebesar 67,28 dan kelompok eksperimen sebesar 74,71, dimana kreativitas berpikir peserta didik yang dilihat dari hasil observasi pada kelompok kontrol tergolong dalam predikat B- dan pada kelompok eksperimen tergolong dalam predikat B. Hal ini berarti bahwa, berdasarkan pengamatan yang dilakukan oleh keempat observer, kreativitas berpikir yang dimiliki oleh peserta didik pada kelompok eksperimen lebih baik dibandingkan kreativitas berpikir yang dimiliki oleh peserta didik pada kelompok kontrol.

3. Kajian Pengaruh Media Pembelajaran Styrobon terhadap Hasil Belajar Kognitif Peserta Didik

Pada penelitian ini peneliti mengujicobakan media pembelajaran styrobon terhadap hasil belajar kognitif peserta didik. Penggunaan media pembelajaran styrobon menuntut peserta didik untuk memahami materi secara mandiri bersama kelompoknya dan merangsang kreativitas berpikir mereka, yang dilihat dari cara mereka memahami materi dengan menggunakan media styrobon dan menuliskannya kembali dalam bentuk ringkasan. Dalam hal ini peserta didik diberi kesempatan untuk membangun konsep dan arah pikirnya sendiri. Berdasarkan serangkaian kegiatan pembelajaran tersebut, hasil belajar peserta didik diukur melalui pretest dan posttest. Pertemuan pertama digunakan untuk pretest dan pertemuan kelima digunakan untuk posttest.

Hasil analisis skor hasil belajar kognitif dari data posttest untuk tiap butir soal dapat dilihat pada Gambar 5 berikut.

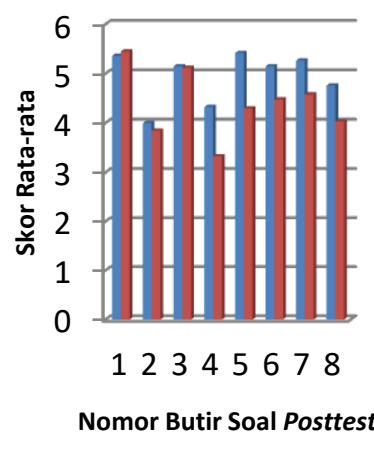

Rata-rata Skor Kelas Eksperimen

Rata-rata Skor Kelas Kontrol 
Gambar 5. Grafik Skor Rata-Rata Tes Hasil Belajar Kognitif (posttest) Tiap Butir Soal

Adapun untuk skor hasil belajar dari data posttest untuk tiap aspek kreativitas berpikir dapat dilihat dalam Gambar 6 berikut.

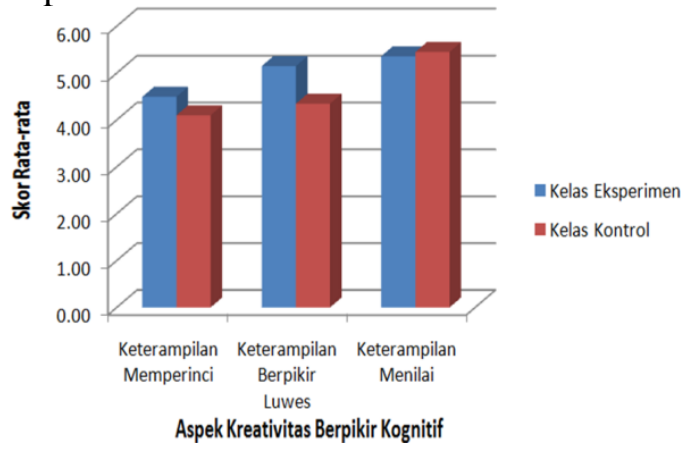

Gambar 6. Grafik Skor Rata-Rata Tes Hasil Belajar Kognitif (posttest) Tiap Aspek

Dari grafik di atas, secara deskriptif dapat diketahui bahwa perolehan hasil skor tes hasil belajar kognitif pada data posttest, baik yang dilihat dari tiap butir soal maupun tiap aspek kreativitas berpikir, kelompok eksperimen rata-rata memiliki skor yang lebih tinggi jika dibandingkan dengan kelompok kontrol.

Pada aspek keterampilan menilai (soal nomor 1), kelompok kontrol memiliki skor rata-rata lebih tinggi daripada kelompok eksperimen. Hal ini disebabkan karena peserta didik pada kelompok kontrol dengan menggunakan media power point lebih mudah menentukan pertanyaan atau gagasan benar atau salah (keterampilan menilai) daripada kelas eksperimen yang menggunakan media styrobon yang baru peserta didik kenal. Keterampilan memperinci (soal nomor 2, 3, 4), peserta didik kelas eksperimen lebih mudah memperkaya dan mengembangkan suatu gagasan dalam mengerjakan soal dengan menggunakan media styrobon dibandingkan media power point karena media styrobon dapat membuat peserta didik lebih memahami materi. Keterampilan berpikir luwes (soal nomor 5, 6, 7,8), peserta didik kelompok eksperimen lebih mudah menghasilkan banyak gagasan dan jawaban dalam mengerjakan soal dibandingkan kelompok kontrol yang menggunakan media power point karena melalui media styrobon yang berbentuk tiga dimensi dapat membuat materi lebih konkret sehingga dapat memiliki banyak gagasan dalam mengerjakan soal. Berdasarkan hal tersebut dapat disimpulkan bahwa media styrobon dapat membuat materi menjadi lebih konkret sehingga dapat meningkatkan kemampuan atau gagasan peserta didik dalam mengembangkan jawaban. Oleh karena itu, media styrobon efektif untuk meningkatkan kemampuan kreativitas berpikir kognitif peserta didik.

Sementara itu, secara deskriptif ratarata nilai posttest pada kelompok eksperimen lebih tinggi dibandingkan kelompok kontrol. Rata-rata nilai posttest pada kelompok eksperimen adalah 81,78 sementara pada kelompok kontrol 73,23. Selain rata-rata nilai posttest, rata-rata nilai pretest kelompok eksperimen juga lebih tinggi dibandingkan dengan kelompok kontrol, yaitu rata-rata nilai pretest pada kelompok eksperimen sebesar 8,02 sementara pada kelompok kontrol sebesar 5,81 .

Hasil deskriptif tersebut tidak dapat langsung ditarik kesimpulan, perlu dilakukan bukti secara uji statistik. Terlebih dahulu dilakukan uji prasyarat berupa uji normalitas dan uji homogenitas. Berdasarkan uji normalitas data posttest diperoleh nilai Sig. 0,179 (>0,05) untuk kelompok kontrol dan Sig. 0,001 $(<0,05)$ untuk kelompok eksperimen, sehingga dapat disimpulkan bahwa data posttest pada kelompok kontrol sudah terdistribusi normal, sedangkan pada kelompok eksperimen tidak terdistribusi normal. Sementara itu, berdasarkan uji homogenitas data posttest diperoleh nilai Sig. 0,064. $(>0,05)$ sehingga dapat disimpulkan bahwa data posttest tersebut homogen. Dikarenakan masih terdapat kelompok yang tidak terdistribusi normal, maka uji prasyarat tidak terpenuhi, sehingga uji statistik yang dapat digunakan yaitu uji Mann-Whitney.

Berdasarkan uji Mann-Whitney, data posttest kelompok kontrol dan kelompok eksperimen diperoleh nilai Sig. 0,044. Nilai Sig. tersebut kurang dari 0,05 sehingga $\mathrm{H}_{0}$ ditolak, yang artinya terdapat perbedaan yang signifikan antara kelompok eksperimen dengan kelompok kontrol. Dengan demikian, penggunaan media pembelajaran styrobon berpengaruh terhadap hasil belajar kognitif peserta didik.

\section{Simpulan dan Saran}

\section{Simpulan}

Berdasarkan hasil penelitian dan pembahasan, maka dapat diperoleh beberapa kesimpulan sebagai berikut. 
1. Terdapat perbedaan yang signifikan dari penggunaan media pembelajaran styrobon terhadap kreativitas berpikir peserta didik. Hal ini dibuktikan dengan hasil nilai Sig. (2tailed) dari uji Mann-Whitney yaitu sebesar 0,049 , lebih kecil dari 0,05 . Hal ini berarti $\mathrm{H}_{0}$ ditolak. Artinya, media pembelajaran styrobon berpengaruh terhadap kreativitas berpikir peserta didik.

2. Terdapat perbedaan yang signifikan dari penggunaan media pembelajaran styrobon terhadap hasil belajar kognitif peserta didik. Hal ini dibuktikan dengan hasil nilai Sig. (2tailed) dari uji Mann-Whitney yaitu sebesar 0,044 , lebih kecil dari 0.05 . Hal ini berarti $\mathrm{H}_{0}$ ditolak. Artinya, media pembelajaran styrobon berpengaruh terhadap hasil belajar kognitif peserta didik.

\section{Saran}

Saran yang dapat diberikan peneliti setelah melaksanakan penelitian adalah sebagai berikut.

1. Bagi Pendidik, proses pembelajaran diharapkan tidak hanya menggunakan media pembelajaran saja, tetapi perlu adanya kombinasi antara media pembelajaran dengan model pembelajaran yang sesuai, sehingga variabel yang ingin dikembangkan atau ditingkatkan dapat lebih terlihat. Disamping itu, selain hasil belajar karakter peserta didik yang juga perlu diperbaiki adalah kreativitas.

2. Bagi Peneliti, perlu adanya penelitian lebih lanjut terkait penggunaan media pembelajaran dalam meningkatkan kreativitas berpikir peserta didik dalam mata pelajaran kimia pada materi pokok lain. Selain itu, perlu adanya modifikasi dan pengembagan media styrobon menjadi media yang lebih baik, ramah dan mudah untuk digunakan, sehingga tidak hanya dapat memicu peningkatan kreativitas berpikir peserta didik tetapi juga benar-benar dapat membantu peserta didik dalam memahami suatu materi yang dapat membuat pencapaian hasil belajar menjadi lebih baik.

\section{Daftar Pustaka}

Arifin, M. (1995). Pengembangan program pengajaran bidang kimia. Surabaya: Airlangga University Press
Arikunto, S. (2002). Prosedur penelitian, suatu pendekatan praktek. Jakarta: Rineka Cipta.

Darmawan. (2013). Metode penelitian kuantitatif. Bandung: Remaja Rosdakarya.

Dewi Satria Ahmar. (2016). Hubungan antara kemampuan awal dengan kemampuan berpikir kreatif dalam kimia peserta didik kelas XI IPA SMA negeri se-kabupaten Takalar. Skripsi, tidak dipublikasikan. Universitas Negeri Malang.

Ibrahim, D. (2014). Metodologi penelitian dalam kajian islam (suatu upaya iktisyaf metode-Metode muslim klasik). Universitas Islam Negeri Raden Fatah Palembang.

Ika Humaeroh. (2016). Analisis kemampuan berpikir kreatif siswa pada materi elektrokimia melalui model open-ended problems. Skripsi, tidak dipublikasikan.UIN Syarif Hidayatullah Jakarta.

Kemendikbud. (2013). Pedoman penilaian hasil belajar. Jakarta: Kemendikbud

Maghfirah, dkk. (2017). Pengaruh model problem based learning (PBL) disertai media tiga dimensi terhadap kemampuan berpikir kreatif siswa dan hasil belajarsiswa dalam pembelajaran fisika di SMA negeri 4 Jember. Jurnal Pembelajaran Fisika, 6 (1), 35.

Ali Mahmudi. (2007). Meningkatkan kreativitas siswa melalui problem posing. Skripsi, tidak dipublikasikan. Universitas Negeri Yogyakarta.

Munandar, U. (2002). Kreativitas dan keberbakatan. Jakarta: PT Gramedia. 
Munzil, dkk. (2017). Miskonsepsi pada materi gugus fungsi dan potensi strategi konflik kognitif berbasis multipel representasi dalam memperbaikinya. Skripsi, tidak dipublikasikan. Universitas Negeri Malang.

Nizam. (2016). Ringkasan hasil-hasil asesmen belajar dari hasil UN, PISA, TIMSS dan INAP. Jakarta: Pusat Penilaian Pendidikan Badan Penelitian dan Pengembangan Kemneterian Pendidikan dan Kebudayaan.

Muhammad Nuh. (2013) SalinanPeraturan Menteri Pendidikan Pendidikan Dan Kebudayaan Republik Indonesia Nomor 69 Tahun 2013 Tentang Kerangka Dasar Dan Struktur
Kurikulum Sekolah Menengah Atas/Madrasah Aliyah. Jakarta: Kemendikbud.

Rahayu, I. (2009). Praktis belajar kimia 1. Jakarta: Departemen Pendidikan Nasional.

Sanjaya, W. (2011). Perencanaan dan desain sistem pembelajaran. Jakarta: Kencana.

Sugiyono. (2015). Metode penelitian pendidikan (pendekatan kuantitatif, kualitatif, dan $R \& D$ ). Bandung: Alfabeta.

Tite Juliantine. (2009). Pengembangan kreativitas siswa melalui implementasi model pembelajaran inkuiri dalam pendidikan jasmani. Skripsi, tidak dipublikasikan. Universitas Pendidikan Indonesia. 